\title{
CORRECTION
}

\section{Correction to: Treatment Persistence in Patients Cycling on Subcutaneous Tumor Necrosis Factor- Alpha Inhibitors in Inflammatory Arthritis: A Retrospective Study}

Johan Dalén · Amy Puenpatom · Karin Luttropp · Axel Svedbom •

Christopher M. Black

Published online: November 8, 2021

(C) Springer Healthcare Ltd., part of Springer Nature 2021

Correction to: Adv Ther

https://doi.org/10.1007/s12325-021-01879-4

The affiliation of corresponding author is Center for Observational and Real-World Evidence, Merck \& Co., Inc, Kenilworth, NJ, USA.

The original article has been updated.

The original article can be found online at https://doi. org/10.1007/s12325-021-01879-4.

J. Dalén · K. Luttropp · A. Svedbom ICON Plc, Stockholm, Sweden

A. Puenpatom $(\varangle) \cdot$ C. M. Black Center for Observational and Real-World Evidence, Merck \& Co., Inc, Kenilworth, NJ, USA

e-mail: puenpatom.amy@merck.com

\section{A. Puenpatom}

Center for Observational and Real-World Evidence (CORE), Merck \& Co., Inc., 351 Sumneytown Pike, North Wales, PA 19454, USA 